Croxson, M. S., Hall, T. D., Kletzky, O. A., Jaramillo, J. E. and Nicoloff, J. T., 1977 “Decreased serum thyrotropin induced by fasting". J.Clin. Endocrinol.Metab. 45: 560-568.

Galbo, H., Hummer, L., Petersen, I. B., Christensen, N. J. and Bie, N., 1977 "Thyroid and testicular hormone responses to graded and prolonged exercise in man". Eur.J.Appl.Physiol. 36: 101-106.

Refsun, H. E. and Stromme, S. B., 1979 "Serum thyroxine, tri-iodothyronine, and thyroid stimulating hormone after prolonged heavy exercise". Scand.J.Clin. Invest. 39: 455-459.

Terjung, R. L. and Tipton, C. M., 1971 "Plasma thyroxine and thyroid stimulating hormone levels during submaximal exercise in humans". Am.J.Physiol. 220: 1840-1845.

\title{
OBITUARY
}

\section{Mr. John Jesse}

With the death of John Jesse on July 6th, 1981, the USA have lost an outstanding coach, and the world a prolific writer of books on fitness and training for many sports. Before entering his 'teens, John started to train seriously, using a weight training programme many years before it became common amongst athletes. He obtained an athletic scholarship at the University of Southern California, and subsequently joined the State Police Force, where his expertise and tremendous enthusiasm helped to promote physical fitness in the Force. Later he devoted much of his time to writing articles and handbooks on training, which showed good insight into the physiological and biomechanical problems contributing to poor performance and liability to injury. For over thirty years he has promoted the need for fitness in educational establishments, developed techniques for advanced training, and was appointed head track and field coach to the United States Olympic Team in 1968. He joined many organisations dealing with sports medicine and training, such as the American College of Sports Medicine, the Australian Sports Medicine Federation, the New Zealand Sports Medicine Federation, the Canadian Association of Health, Physical Education and Recreation, and was one of the first overseas members of the British Association of Sport and Medicine, joining us in 1967. He contributed articles to our Journal, kept up an interesting correspondence, and paid his last visit to Europe two years ago, travelling specially from London to Loughborough for the purpose of making personal contact, and bringing his wife with him as a very welcome guest. He realised that he was an ill man, and has spent the past year and a half rushing to complete his life's work. I was very impressed with his enormous enthusiasm, and his insight into positive health as a way of preventing disease, as well as his everlasting interest in improving the standard of athletic fitness and performance.

Our sympathy is extended to his wife and son, who still live in Hermosa Beach, California.

H. E. Robson 